\title{
Trickling Sluggishly of Voluntary Service from the Perspective of Human Resource Management
}

\author{
SHU-CHEN WANG \\ School of Economics and Management, Fuzhou University \\ Fuzhou Fujian, China \\ 3419393075@qq.com
}

\begin{abstract}
This paper takes the case study of nusing institutions, Introducing social volunteer service collaboration from the perspective of human resources, The qualitative research method and purposive sampling method conducted indepth interviews, a detailed analysis of the trickling sluggishly of volunteer collaboration in micro nusing institutions is presented. The social structure of Taiwan has changed greatly, increase voluntary investment, voluntary activities play a role of multi innovation, attracting attention and discussion. Starting from three perspectives, selecting a good leadership team is a partnership, the retention of task volunteers, learning innovation cooperation relations, analysis of its successful experience in human resource management practice, finally, suggestions are given to the shortage of human resource management practices in nusing institutions and social volunteers.
\end{abstract}

Keywords-Miniaturen nusing institutions; Human Resource management; Volunteering; Trickling sluggishly

\section{INTRODUCTION}

To meet the needs of environmental change, university courses and Learning model, strive for new ideas and new social values of learners, teachers, communities and stakeholders.

Lack of students in Taiwan has seriously affected college students, leading to a positive transformation of strategies, seeking sustainable development, and enhancing internal and external value innovation. In the ten years of the study, most of the enterprises to create maximum profit, or profit, or to maintain the advanced enterprise image ranking leader, or to participate in voluntary service in different output mode, preset the results of enterprises output value. In the process of concrete value creation process and situation integration, linking corporate social responsibility (CSR) and human resource management to construct the synergistic effect of both, the exchange of relevant transparent information, access, or substantive results will help to expand opportunities for value creation among stakeholders.

Enterprises are facing the future of sustainable development an important challenge (Carroll, A.B. and Shaman, K.M. 2010; Neville 2011; Aquinas and Guavas 2012), the implementation of corporate social responsibility into practice and performance management, affects the current management issues.
This article is based on the Open University "Civil society participation, service learning" and volunteer service practices are the research areas, exploring the derivative effect of university volunteer service by CSR-HRM cooperation. After five years of students is visiting a class and propaganda, students are transferred from non-degree courses to formal courses in Universities; continuous learning is likely to face high challenges of choice and exit. Service learning through practice, care for the disadvantaged of face-to-face service, combined with NPO and other extended depth services, learners gradually perceive the value, capacity and innovation of services needed in the community, arouse interest in this research. Through existing social capital and grassroots services, collect relevant literature, through case and expert interviews, structural questionnaire was used to compare the enrollment of students, the evaluation study process and achievement, repeated view learners and common collaborator, reliability of validity and validity of learning behavior in volunteer service. The research on service learning and common collaborators, to understand the current situation and future trends of student development continue to improve the learning field service strategy.

Collaborators include schools, Non-profit Organization (NPO) and public sectors. In the past NPO corporate social responsibility practice has always been regarded as behoove, internal partnership is to promote the public welfare activities, the cumulative reputation and create the necessary elements of service performance, NPO over the years to promote CSR face financial, scale and professional ability, curriculum planning based on leveraging the power of NPO, application strategy of human resource management in university with the strategic cooperation practice CSR. Based on the HRM model, practice of applying CSR (CSR-HRM co-creation created model) management literature, as support for voluntary service process dynamic background, application, target and transfer value and contribution possible, through the school, community, community cohesion, corporate and government (bonding) and (bridging) formation across the awareness of the role of collective action in the community, the output value of sharing between members, to create the citizenship behavior social acceptance and good interaction. The purpose of this study: 1.Service learning practice model of voluntary students. 2. Discuss service learning, HRM-CSR collaboration, strategic human resource management, how to reflect the innovation ability and social responsibility of students. 


\section{BACKGROUND: VOLUNTEER SERVICE IN THE UNIVERSITY}

The Ministry of education in October 2000, revised university service learning programmed, The school combines the activities of the former students with voluntary service activities, or combines the existing courses with social service activities or internships. Since December 2012, the Open University of civil aviation has adopted the curriculum and teaching planning committee meeting to develop a "civil society participation service learning" (service learning) two credit courses: the one by the instructor led and guide students on campus service work.

Second, the teacher will lead and guide the students to the community or NPO for service operations. In theory, the "civil society", including differences of field and organizational units, citizens spontaneously initiated voluntary association, jointly solve problems, therefore, around the common economic interests, goals and values on the field; usually the association and the operation in the community, environmental protection, women, religion, charity, social sports groups, by organizing a community of citizens (civic community) to participate in public affairs, learning attitude of tolerance and mutual respect, trust, tolerance and unity of positive association.

\section{LITERATURE ON VOLUNTARY SERVICE CASES AND PRACTICE OF CSR}

Collaborative partnerships in volunteering, when participants sense the organization's trust and attention to it, the participants generate rewards, and the organization has a certain sense of commitment, this sense of duty drives participants to achieve organizational goals. On the other hand, when participants feel respected and cared for during the service process, facilitate peer collaboration and role identification, increase organizational commitment, reduce turnover or quit curriculum learning. The combination of curriculum and service learning is the key to the implementation of "citizen service" activities, students participate in regional service model, linking corporate social responsibility, adult learners may be created to experience reflective multiples of learning growth, the commitment of learners to corporate social responsibility, more recognition of public relations is one of the most important tools in current human resource management practices

Stakeholders continue to focus on CSR practices, these CSR related topics can lead to a study of organizational and social needs, such as sustainability, appropriate stakeholders, management and environmental and social responsibilities. Chowhan (2013) considers, In HRM practices, such as reinforcement, motivation, and opportunity, innovation shows little attention. When organized, personally feel that the independent contribution can affect the work practice or authorized by creating opportunities for contribution may lead to the greatest advantage of self. In this paper, the case of Changhua class taking part in diversity service learning is taken as an example. The participants have the opportunity to contact each other with their backgrounds, industry and experience, in the service learning process, challenge the self-existing stereotype or rigid thinking to study, understanding and learning about the difference in respect for others leads to change of ideas and self-growth. It also includes the field of services and the choice of service organizations, process arrangement, service and service time, give learners full scope and intelligence.

Through collective collaboration, thinking and information exchange, the shared utility of knowledge sharing, sharing, and collective intelligence, to produce more favorable ideas, an organization that creates and maintains long-term, sustainable competitive advantage, because it is beneficial to produce new and better ideas, processes, products and services, knowledge sharing is a new knowledge driven formation mechanism, knowledge sharing proved to lead to improvements in innovation ability. In addition to knowledge learning, past experience can also lead to learning, especially the volunteer service participants especially. The experiential Learning cycle presented by Kolb in 1984 (Fig.1), explain how experience becomes an idea, again, use existing concepts to guide new experiences.

\section{OPEN UNIVERSITY}

The Open University was founded in 1986, it is the tenth official university in Taiwan, the heyday reached fifty thousand students, is the largest number of students in the country's Universities, Open University flexible learning has the benefit 180 million students (2016.11), especially those with disabilities, partial Islands and those who committed punishment. There is no room for public administration, management and information and life sciences, business study, department of Social Sciences, thirteen learning guidance centers. The $20 \%$ old college admission rate of elite education, nowadays, we are faced with fewer children and higher education, the popularity of digital challenge, only more twelve thousand students. When the University was founded, the students were generally employed by public servants and middle-aged, reflux, mostly educated, after 2011, students gradually become younger(2013) the establishment of Nantou class, the average age is about 43 years old, accounting for $1.3 \%$ of the age of 60 ,Chang-hua class (2014) was established,

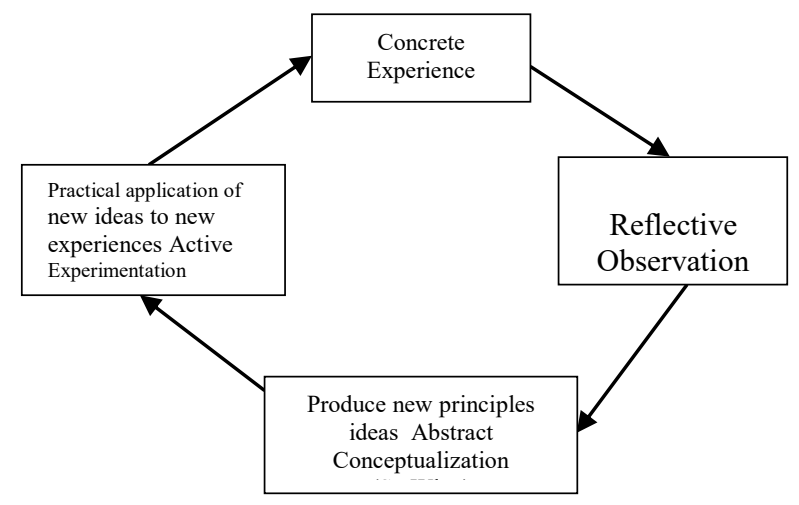

Fig.1 The experiential Learning cycle presented (Kolb, 1984) 
The average age of about 55 years old, service learning students learning show, in addition to a commitment to continuous learning until graduation, mainly through classroom teaching and dispelling, before and after voluntary service practice, the learners learning reflection, ingrained traditional ethics and sense of honor. The subjects of this study are mainly from the rural areas, and higher education is not the biggest incentive for some learners.

The assessment mechanism of learning process influences the willingness to continue learning. In the past, the examination of 128 large credits was almost equivalent to the difficulty of national examinations, and the short-term degree was very few. According to this, returned to his alma mater to serve the devotees, learning experience, community participation, promotion programs, community service and other aspects, and focus on the depth and breadth of "service learning" practice, may become a kind of offbeat benchmarking model, worthy of discussion in the application of human resource management.

\section{THE SOURCE OF SERVICE LEARNING}

In this paper, service learning courses, empirical counseling volunteer service of the six stages of the model: (1) preparation stage: setting students enrollment, in the local geographical and ecological environment as the foundation, through long-term construction of social capital network of stakeholders' visit; (2) students: students confirm stage the description of the course; (3) students service stage: strengthen administrative capacity links to social welfare organizations and cultural and creative industries and leading media industry, the establishment of information exchange platform; (4) students learning stage: recording, cognitive organizational vision and mission, our personal career goal, case analysis, two-way exchange of experience, identification of volunteer service; (5) students self-satisfaction stage: Exploration and implementation of environmental project management services, default incentives and recognition for students; (6) tracking stage: response service The effectiveness of the "soft power", whether the services of the individual inputs meet the expectations of the group, and instead of experiential training through experiential reflection, takes into account the self-esteem of the trainees and the recipients, and conforms to the characteristics of the learner's honor and autonomy. In the selection of human resource management with discipline, the introduction of external organizations, volunteer service enterprise, and retain employees as an important component of a corporate reputation and performance strategy. Enterprises in order to meet stakeholder needs, providing volunteer services, encourage high order leading social responsibility behavior into the core business, the staff for the benefit of the community and the contribution of the attitude held positive views and concerns.

TABLE I A SPECIFIC BACKGROUND SURVEY ON THE IMPLEMENTATION OF CORPORATE SOCIAL RESPONSIBILITY STRATEGIES BY STAKEHOLDERS

\begin{tabular}{|c|c|c|c|c|c|c|c|c|c|c|c|}
\hline & \multirow{2}{*}{\multicolumn{2}{|c|}{$\begin{array}{l}\text { Student (volunteer) } \\
\quad \text { Volunteer }\end{array}$}} & \multirow{2}{*}{\multicolumn{2}{|c|}{$\begin{array}{l}\text { NPO- Association } \\
\text { Volunteers / } \\
\text { consultants (business } \\
\text { owners) }\end{array}$}} & \multicolumn{2}{|c|}{$\begin{array}{l}\text { Social welfare } \\
\text { organization }\end{array}$} & \multicolumn{2}{|c|}{$\begin{array}{l}\text { Social welfare } \\
\text { organization }\end{array}$} & \multicolumn{2}{|c|}{ Street artist } & \multirow{3}{*}{ Media Spread } \\
\hline & & & & & Employee & $\begin{array}{l}\text { Receive } \\
\text { service }\end{array}$ & Employee & $\begin{array}{l}\text { Receive } \\
\text { service }\end{array}$ & $\begin{array}{c}\text { Individ- } \\
\text { ual }\end{array}$ & Group & \\
\hline \multirow{2}{*}{$\begin{array}{c}\text { Gender } \\
\text { Percentage }\end{array}$} & $14 \mathrm{~g}$ & $93 \%$ & $21 \mathrm{~g}$ & $61 \%$ & $6 \mathrm{~g}$ & $68 \%$ & $6 \mathrm{~g}$ & $60 \%$ & & & \\
\hline & $1 \mathrm{~b}$ & $7 \%$ & $14 \mathrm{~b}$ & $39 \%$ & $4 b$ & $32 \%$ & $4 \mathrm{~b}$ & $40 \%$ & & & \\
\hline \multirow{4}{*}{ Age } & $25-35$ & 0 & $25-35$ & $19 \%$ & $10 \%$ & 0 & $10 \%$ & 0 & & & 1 \\
\hline & $36-45$ & $50 \%$ & $36-45$ & $20 \%$ & $40 \%$ & 0 & $40 \%$ & 0 & & & 4 \\
\hline & $46-55$ & $26 \%$ & $46-55$ & $32 \%$ & $30 \%$ & $15 \%$ & $30 \%$ & $15 \%$ & & & 2 \\
\hline & $>56$ & $26 \%$ & $>56$ & $29 \%$ & $20 \%$ & $85 \%$ & $20 \%$ & $85 \%$ & 2 & 18 & 1 \\
\hline umbers & \multicolumn{2}{|c|}{15} & \multicolumn{2}{|c|}{$35 / 35$} & $5 / 10$ & $10 / 50$ & $4 / 10$ & $20 / 55$ & & & $6 / 8$ \\
\hline \multirow{3}{*}{$\begin{array}{c}\text { Community } \\
\text { Experience } \\
\text { Seniority } \\
\end{array}$} & $<10$ & $77 \%$ & $43 \%$ & & $80 \%$ & & & & & & \\
\hline & $10-20$ & $10 \%$ & $23 \%$ & & $10 \%$ & & & & & & \\
\hline & $>20$ & $13 \%$ & $34 \%$ & & $10 \%$ & & & & & & \\
\hline $\begin{array}{c}\text { HRM+ } \\
\text { CSR } \\
\text { Cooperation } \\
\text { public } \\
\text { welfare }\end{array}$ & \multicolumn{11}{|c|}{$\begin{array}{l}\text { 2000p/ time/ (2012 Chong yang./ matchmaker/ Sakura season) } \\
\text { y care / community/ haircuts skills competition charity donation/ Home Finance Industry Guide) }\end{array}$} \\
\hline
\end{tabular}

(data are dictated by social welfare agencies, written by the staff, and collated by the authors) under the advocation of NPO human resource management department (2013-2017)

\section{Human Resource MANAGEMENT Roles IN CSR AND NPO}

According to Ulrich (1997) four task roles HRM mode, CSR volunteer service is planned. First role of a partner: strategy, Human Resources Manager (CEO) and human resource strategy recommendations of the organization preliminary link, the role of passing an execute CSR strategy; to work together to create value for the vision, let stakeholders see. In order to achieve this role, managers need to have information, financial risk and control capabilities; human resource management practices need to be consistent with the
CSR implementation goals in order to create valuable results. Therefore, managers must have other leadership functions in a collaborative strategy. Provide guidelines for volunteering activities or a flow chart of the CSR-HRM collaboration model, provide an explanation of the possible intervention of the HRM role in the future or in the process of interpreting an effective partner, how can human resources management and corporate social responsibility be integrated to achieve potential incremental value and sustained competitive results (results and values)?Second roles: Change agents provide a more competitive new organization, primarily to specifically achieve and maintain the competitive edge of the organization, 
responding to inevitable trends and adopting a response mechanism, especially in the constantly changing pattern of competition, HRM must take concrete action, assist managers in collaboration to monitor and respond to major changes in their business environment. Human resource managers need to assist in collaborative business development and communicate clear vision of future goals, the act of providing agreement with a goal and develop incentives and rewards, overcome the resistance of collaboration and NPO members to change in the process. For example, a fundamental change in organizational vision, strategy and organization operation, need leadership (what to do), management (work to complete), motivating members to cross new thinking and direction, obtain new functions and make organizational contributions and results in a new way. In this case, the human resource manager (CEO) adds value, to assist the organization or individual cooperation, the transition from the old to the new state of mind the competition situation. Third roles, administrative experts, provide effective collaborative processes. In the field of HRM, macro the level of knowledge and skills involved in the identification of value-added opportunities for human resource managers. For example, knowledge and technology of activity planning are presented, Improving service levels and reducing costs may increase the results, values, etc. shared by cooperation and managers. Fourth roles, excellent employees, maximize employee contribution and organizational commitment. Human resource managers listening and respond to cooperation requirements and available resources, the members of the situation and the problem of concern is the It differs from man to man., long-term problems, and the legal norms. The empirical research of voluntary service under cooperation, expectations of creating value goals are often accepted by specific stakeholders, continuing incentive activities continue to exist, including, positive reputation marketing, parenting relationship and communication increase, employment rate promotion, quality employees, workplace environment and climate change.

\section{CSR-HRM COOPERATION}

Corporate social responsibility affect the direction of enterprises, enterprises may think that strong CSR may enhance the productivity of innovation, especially the strategy of CSR, related to corporate social responsibility based on the reputation or difference (e.g., Boehe and Cruz 2010) the use of innovation. The air service learning courses in the practice process, must through the theory of distance education, the evaluation of knowledge level, finally remedial school knowledge internalization behavior after; curriculum planning, written into the local community service situation, after the establishment of a certain degree of social capital network, and lead the students on the basis of community. Plans to carry out voluntary service cooperation, joint decision-making of volunteer service demand is to get timely feedback.

For a long time, the discussion of corporate social responsibility has been discussed by scholars from the government and the academic circles, and each has its own similarities and differences. Brik et al. (2011) believes that the ability of corporate social responsibility practice gives enterprises, increase employee commitment to the organization, have a positive impact on enterprise performance; experts and scholars emphasized the importance of human resource management activities to meet internal customer needs at the same time, also indirectly influence the attitude and behavior of external customers, which meet the needs of the participants and perceptual organization support CSR returns (derived psychological influence of metaphor role and exemplary), the interaction between the two, may therefore strengthen volunteer responsible social action or conform to organizational citizenship behavior. Any automatic input care for the disadvantaged or community service, or passive with private sector activities, or with social welfare groups, resulting in regional service activities in the process of extension become a positive image effect (Richard Borghesi, Joel F. Houston, Andy Naranjonaranjo, 2014) is the trend in the case. This study suggests that service learning resource integration has its specific meaning and necessity of promotion, cooperation is key to NPO managers, management plan of the audit (assessment of resources) and writing programs - teachers (resource integration); media industry reporter (PR Marketing); Wen Chong industry team buskers (skills and emotion); SWOs CSR executive family task team, by the service, the NPO service; management of human resources managers and volunteers; government departments to implement the policy of business people the practice of CSR.

\section{CONCLUSIONS AND RECOMMENDATIONS}

The stakeholders have an impact on the organizational goals and goals, and NPO and NGO should bear certain social responsibility for the public interest. The CSR-HRM strategy (volunteering) collaborative model emphasizes knowledge transfer and absorption. "Know what to do?"". Volunteer service innovation is part of the university curriculum, and stakeholders introduce the "drive enterprise" based on the role of "volunteer service""'. The results are as follows: first of all, with the diversity of social public service activities, it is of positive significance to integrate service learning into CSRHRM cooperation. Volunteer service practice will improve learners' willingness to learn and influence. Learners' commitment to team work, understanding of organizational management practices, and norms are likely to lead to commitment and become positive energy for social capital. Provision of public services, preparation of deadlines and areas, increased cohesion in the workplace and continued willingness to participate in external social responsibility and position. However, in many unpredictable social changes, stakeholders may opt for interest alliances rather than common goals, and may even be unrelated to or unknown to their knowledge. Forprofit or nonprofit enterprise management is a kind of art, cooperative mode with different background stakeholders embedded in HRM and CSR, giving shareholders, employees and stakeholders of team culture bring economic benefits to the benefit and social value, promote the university volunteer service, the enthusiasm of the students to complete their studies of the strong chemical.

This paper argues that the need to value innovation what (CSR and voluntary service activities), share the mutual understanding of the decision (HRM-CSR strategy), the process of innovation in voluntary service (CSR) involves 
formal interaction, specific service process, evaluation, and administrative data base adjustment. In addition, the CSR program information transparent access or exchange, "the output value" to clear data set out the index of success, especially, everyone may have his own opinion to support what kind of value innovation is effective. It also shows that knowledge sharing and communication in volunteer service collaboration (CSR strategies) can lead to an emerging output, outcome, or value.

\section{REFERENCES}

[1] Carroll, A.B. and Shaman, K.M. 2010. 'The business case for corporate social responsibility: a review of concepts, research and practice'. International Journal of Management Reviews, 12:1, 85-105.

[2] Jamali, D. and Neville, B. 2011. 'Convergence vs. divergence in CSR in developing countries: an embedded multi-layered institutional lens'. Journal of Business Ethics, 102, 599-621.

[3] Aquinas and Guavas, A. 2012. 'What we know and don't know about corporate social responsibility: a review and research agenda'. Journal of Management, 38:4, 932-968.

[4] Aslam Khan, Mohammad(2017).The Co-relational study of CSR and Consumer Behaviour: A Study of FMCG sector in Delhi and NCR. Amity Global Business Review.8:1, p74-80

[5] Van, der, Voort, Glac, and meijs( 2009).Managing Corporate Community Involvement. Journal of Business Ethics.p 311-329. Waddock, A., "Building Successful Partnerships", Sloan Management Review, 1988, pp. 17-23.

[6] Boehe, D., \& Cruz, L. (2010). Corporate social responsibility, product differentiation strategy and export performance. Journal of Business Ethics, 91, 325-346.

[7] Brik, A. B., Rettab, B., \& Mellahi, K. (2011). Market orientation, corporate social responsibility, and business performance. Journal of Business Ethics, 99(3),307-324

[8] Richard Borghesi, Joel F.Houston, Andy Naranjo(2014) Corporate Socially Responsible Investments: CEO Altruism, Reputation, and Shareholder Interests, Journal of Corporate Finance 26, 164-181.

[9] Murphy, M., \& Arenas, D. (2011). Through indigenous lenses: Crosssector collaborations with fringe stakeholders. Journal of Business Ethics, 94(1), 103-121. 